\title{
Public Policy Processes and Sustainability in the Minerals and Energy Industries
}

\author{
CIARAN O’FAIRCHEALLAIGH
}

Griffith University

Nathan 4111

Australia

e mail: Ciaran.Ofaircheallaigh@griffith.edu.au

\begin{abstract}
This chapter considers the extent to which public policy processes are geared towards sustainability in mineral industries, and how they may need to change to take the requirements for sustainability into account. It begins with a general discussion of sustainability in mineral industries, drawing on examples from three countries. As these examples show mining is neither inherently sustainable nor unsustainable, but rather is made sustainable or unsustainable, in large part by public policies applied to the mining industry. The nature and content of public policies reflect, in turn, the policy making processes utilised in formulating and implementing policy, and so it is critical to consider the links between policy processes and sustainability. Nine specific variables are identified that shape public these processes, including the identity and number of interests or groups involved in making policy and how much influence they exert; the range of policy alternatives considered; time frames and information sources for policy making; the time periods over which the impacts of policy alternatives are considered; and the criteria applied by policy makers. The chapter argues that current policy making processes in relation to mineral industries are often incompatible with the pursuit of sustainability and that radical changes are required if public policies are to support sustainabilty in mineral and energy industries.
\end{abstract}

\section{Introduction}

This chapter focuses on the processes used in making public policies, both in relation to specific mining and energy projects and to policy issues that affect mineral development. This is an issue of central importance to sustainability in mineral industries, given that in most countries minerals are largely or entirely in public ownership, and that governments play a critical role in resource development through policy and legislation dealing, for instance, with planning and land use, environmental impact assessment, environmental management, taxation, corporations, foreign investment and trade, and indigenous land rights. If the content and impact of public policies are not conducive to sustainability in the mineral industries, it is inconceivable that sustainability can be achieved. To put the argument somewhat differently, mining as an industry (as opposed to mining of individual ore bodies) is not either inherently sustainable or inherently unsustainable. It is made sustainable or unsustainable, in large part by public policies, a point illustrated in Section 2. And 
mining cannot be made sustainable if public policies are incompatible with the pursuit of sustainability.

The content of public policies is very much influenced by policy making processes, by the way in which policies are conceived, developed, endorsed and implemented. It follows that the nature of those processes has profound implications for the prospects of achieving sustainability. The implications of public policies for sustainability in mineral industries are increasingly recognised (ICMM 2008, 4-5, 9, 17; MacDonald and Gibson 2006, 4, 13-15; MMSD 2002, xiv, xviii, xxii, xxvi, xxix, 336, 356-57; Richards et al 2004, 62-64). Much less attention has been devoted to the relationship between public policy processes and sustainability, despite the recognition by the Mining, Minerals and Sustainable Development (MMSD) Project, for instance, that 'Decision making-processes are as vital as the end results' (2002, xvii). To the extent that policy processes do attract attention, this tends to focus heavily the issue of public participation and stakeholder engagement (Cheney et al 2002; Day and Affum 1995; Environmental Law Institute 2004; Gao, Akpan and Vanjik 2002; ICCM 2008, 17, 21; MMSD 2002, xx, xxviii-xxix, 346, 354, 401; Weitzner 2002). This is also a feature of the general literature on sustainable development (see for instance Lyons, Smuts and Stephens 2001; Stratford and Jaskolski 2004). But public participation is just one of many variables shaping policy processes (see below). This chapter develops a more broadly-based approach in analysing the way in which public policy processes affect, or can affect, sustainability in mineral development.

While most democratic governments, including Australia's, have committed themselves in principle to the pursuit of sustainability (COAG 1992), it is quite a different matter to devise policy making processes that reflect and promote those principles. Existing processes have developed incrementally over long periods of time when sustainability was not an explicit goal of government policy, and they are not simple or easy to change (Howlett 2002, 241). In addition, there is the very important issue of what sorts of processes are likely to facilitate sustainability in the development of natural resources (or in policy making generally). Even where governments have both the will and capacity to bring about major changes to public policy processes, what sorts of processes should they change to?

This chapter begins by examining the link between public policy processes and sustainability in mineral industries. It briefly discusses the link between policy processes and policy content and outcomes, and then identifies nine variables that, in combination, are critical in defining the nature of public decision making in the context of mineral industries. It illustrates the operation of these variables through two short case studies, of state government policy on natural gas development in Western Australia and of federal policy towards the uranium industry. The discussion highlights the dynamic nature of current processes in Australia; the ways in which they diverge from an approach that would promote sustainability; and the issues involved in pursuing such an approach in relation to resource development in a 'real world' context. While this chapter considers the impact of the nine variables are considered in an Australian context, they have been identified through a review of international literature on policy making and on sustainability in mineral industries. Thus the approach developed here is of much wider applicability. 


\section{Public Policies and Sustainability in Mineral}

\section{Industries}

Drawing on the standard definition of sustainability provided by the Bruntland Commission, sustainability in the minerals industries requires that development of mineral resources should meet 'the needs of the present without compromising the ability of future generations to meet their own needs' (Bruntland 1987). It is possible to argue that given the non-renewable and ultimately finite nature of mineral resources, sustainability in the minerals industries is impossible to achieve, because use of resources by the current generation must inevitably deplete the availability of resources at some time in the future and so compromise the needs of future generations (Ali and O'Faircheallaigh 2007, 7). This argument may be valid if the analysis is restricted to the 'physical' or 'geological' sustainability of mining and is considered over an infinite future, since at some point all mineral resources are potentially subject to exhaustion and this exhaustion may compromise the needs of the generations then living. However sustainability can also be considered in environmental, economic and social terms. Once it is so considered, quite different and more complex conclusions may be reached regarding the 'sustainability' of mineral industries. On the one hand mining activities that appear sustainable over long periods of time in physical or economic terms may prove unsustainable in environmental or social terms. To provide an obvious example, copper mining on Bougainville Island in Papua New Guinea did not cease in 1989 because the Panguna ore body was depleted in a physical sense or no longer profitable to mine, but because social conflict surrounding the project and its environmental impact led to an armed rebellion which permanently closed it (May and Spriggs 1990). Similarly, a failure to achieve social sustainability led Rio Tinto to cease developing one of the largest, lowcost uranium deposits in the world at Jabiluka in Australia's Northern Territory. The Aboriginal traditional owners for the area, the Mirrar, had determined on the basis of their experience with the nearby Ranger uranium mine that, because of its social impact, uranium mining was incompatible with their survival as a people. As a result they undertook a major and ultimately successful legal and political campaign to stop Jabiluka (Katona 2002). On the other hand exploitation of a physically non-renewable resource "may be deemed "sustainable" if there is an effective conversion of the natural capital, represented by the resource, to social capital that would allow for long-term livelihoods' (Ali and O'Faircheallaigh 2007, 6; see also MacDonald and Gibson 2006, 3).

I am not suggesting that different dimensions of sustainability can exist independently of each other in the sense that mineral development could continue if some of these elements were 'present' and others 'absent'. In the real world the various dimensions of sustainability are inextricably linked. However for analytical purposes it is critical to understand that sustainability does have these different dimensions, and that a rigorous analysis of sustainability and mineral industries requires a focus on all of them. And once environmental, economic, and social dimensions of sustainability are incorporated into the analysis, public policies and so public policy processes become critical. This point, and the need to avoid any a priori assumptions about mining and sustainable development, can be illustrated by briefly examining specific examples of mineral development in three different countries. 
The first involves phosphate mining on the Pacific island of Nauru. Mining of Nauru's rich phosphate deposits began in 1906 when the island was still part of the German Empire. Production expanded after World War I when Nauru was entrusted by the League of Nations to the United Kingdom, Australia and New Zealand, and further growth occurred after World War II when Nauru was made a Trust Territory of the United Nations under the trusteeship of Australia. Mining continued after Nauru achieved independence in 1968. The resource is now close to exhaustion; little agricultural land remains on Nauru; most of the island has been reduced to what has been called a 'lunar waste'; and Nauru's economy is in a parlous state (Australian Broadcasting Commission 2005; Howard 1991; Weeramantry 1992). These outcomes appear certain to compromise the needs of future generations of Nauruans in fundamental ways.

Given the limited size of Nauru and its phosphate deposits, commercial mining was not sustainable in a physical sense over the long term. However it does not necessarily follow that mineral development was inevitably unsustainable in economic, environmental or social terms. A critical factor in the outcome that eventuated involved the policies towards the island of the United Kingdom, Australia and New Zealand. The colonial powers allocated only a tiny proportion of the value of phosphate exports to the Nauruans and failed to take any meaningful measures to rehabilitate the island. A Rehabilitation Fund set up for this latter purpose 'stood at the meagre level of $\$ 599,325$ ' when the UN trusteeship ended in 1968 (Weeramantry 1992, 231-35, 283; Howard 1991, 166-94).

At independence, Nauruans were well aware of the problems they faced. The Nauruan government decided to allocate a substantial proportion of the revenues generated by phosphate mining to the Nauru Phosphate Royalties Trust, which undertook a major program of overseas investment designed to create an asset base that would generate ongoing revenue for Nauru after mining ceased. The Trust was used to establish a national airline and shipping company; to build up an international investment portfolio; and to purchase office blocks, hotels and land, especially in Australia and the United States. Many of these investments ran into financial difficulties, with Air Nauru in particular incurring heavy losses and requiring a subsidy equivalent to a third of the government's budget in 1980-1981. Other ventures also ran into financial difficulties and profits on investments were well below expectations (Howard 1991, 175-194; Kearney 2008). By 2002 Nauru was in a dire financial situation and had to seek emergency financial aid of US\$4.8 million from Australia. By 2004 the country was on the brink of bankruptcy, with receivers taking control of Nauru's property investments in Australia due to the country's outstanding \$US165 million debt to America's General Electric Capital Corporation (Australian Broadcasting Corporation 2005).

Nauru was also experiencing significant social problems. The growth of royalty revenue, part of which was paid to individual landowners, led to dramatic changes to the lifestyle of Nauruans. All citizens were guaranteed a basic level of income by government, and certain individuals and families whose land was mined after royalty levels increased received substantial incomes. Lack of agricultural land due to the impact of mining combined with substantial cash incomes and a general tendency to expend these incomes on consumer goods led to a dramatic increase in consumption 
of imported packaged foods, and alcohol consumption also rose rapidly. Over a number of decades serious health problems resulted, with high rates of obesity and of 'lifestyle' illnesses such as diabetes and heart disease. Significant inequalities in income also emerged. In the 1980s the Nauruan government made what Howard describes as a 'half hearted program' to address health problems, with limited results (Howard 1991, 179). Thus by the turn of the $21^{\text {st }}$ century Nauru's social sustainability was also under threat (Australian Broadcasting Commission 2005; Kearney 2008).

Phosphate mining on Nauru has proved not to be sustainable in physical, economic, environmental or social terms. However different outcomes could have eventuated if the colonial authorities pursued different policies and allocated a significant portion of phosphate revenue to environmental and economic sustainability funds over the decades prior to Independence; had Nauru's investment strategy been more successful; and had the Nauruan government pursued different and more effective health and social policies.

The second example involves the Ok Tedi copper mine in the Western province of Papua New Guinea. The Ok Tedi mine is still operating, but it could be argued that it has long since passed the point at which its operations could be said to be sustainable in a broader sense, and that even if it operated for hundreds of years into the future it could never operate sustainably. This is because its presence has destroyed the resource base of hundreds of Papua New Guinea villagers, as a result of the devastating environmental impacts of the release of its tailings and waste rock into the Ok Tedi and Fly rivers. This outcome emerged in large measure from the decision of the Papua New Guinea government to allow the project to proceed after its developers refused to continue with construction of a tailings dam after the original dam site was inundated by a huge land slip. There have also been serious failings in the environmental management and regulatory systems for the mine, which resulted for instance in release of cyanide into the Ok Tedi river in 1984, killing thousands of fish, crocodiles and turtles. The project has certainly imposed huge costs on future (as well as on current) generations, as it will take decades for the river systems to return to health, and as large areas of agricultural land have been permanently lost (Kirsch 1997, 121-26, 2004; MMSD 2002, 348).

Some villagers of the current generation have been compensated for their losses, others have been only partially compensated, and some have received little or no compensation (Banks and Ballard 1997a, 6). It is not at all clear that future generations will receive any compensation (Banks and Ballard 1997b). Even where people have been compensated for economic losses, they have also incurred social and cultural losses that are impossible to quantify or to address in monetary terms. As Kirsch notes, the landscape on which personal and social histories were inscribed, and through which social relations were defined and maintained, has changed irrevocably, and and the birds, animals and fish with whom, in Yonggom cosmology, they maintained intimate and vital relationships have disappeared (Kirsch 2004). In his words, for Yonggom landowners along the Ok Tedi river "environmental damage implies a fundamental change in how [they] view their relationship with the world around them. With reference to to past events becoming increasingly structured by abstract chronologies, their remebrance of things past are no longer linked to their surroundings ... Their environment is no longer a site of productivity, but a scene of 
loss. It no longer provides them with security, but confronts them with new, indecipherable risks' (2004, 191, 197).

In this case, lack of sustainability has largely reflected corporate and government decisions, rather than any inherent characteristics of a large copper mining project. It is of course possible that the project was not, as its developers claimed, economically viable if it had to bear the costs of tailings storage. If this is the case, sustainability could only have been advanced by a decision not to mine.

Let us consider a third scenario, bauxite mining on Cape York in northern Australia, by Rio Tinto Alumina (formerly Comalco Ltd). In this instance mining has already lasted for 40 years, is based on a very extensive and low-cost resource base, and is likely to continue for decades or even hundreds of years into the future. For the first four decades of its life few economic benefits accrued to the traditional Aboriginal owners of the land on which mining occurs, and at the same time they incurred significant social, cultural and environmental costs (O’Faircheallaigh 2005). In 1992 Australia's High Court recognized the existence of Aboriginal native title in Australia in the Mabo case, and in the following year the Federal Government provided legislative recognition of native title through the introduction of the Native Title Act 1993 (NTA). A number of traditional owner groups subsequently lodged native title claims over sections of Comalco's mining leases. Partly in response to these changes, Rio Tinto altered its policies towards Aboriginal communities affected by its operations, and as a result invited traditional owners to negotiate a legally binding agreement covering a range of issues and impacts associated with Comalco's operations (Cape York Land Council/Comalco 2001).

The Western Cape Communities Co-existence Agreement (WCCCA), signed in 2001, includes a system for minimising or avoiding damage to Aboriginal cultural heritage; a review and upgrading of environmental management systems and Aboriginal participation in environmental management; and extensive programs to increase Aboriginal employment and business development opportunities. In terms of economic and social sustainability, a critical part of the agreement involves payment of substantial royalties to the traditional owners both by Queensland's state government and by the project operator, and investment of over half of this revenue flow in a long-term capital fund which operates on prudential rules designed to maximise returns while minimising risk. Income is reinvested for 20 years, after which it becomes available for current expenditure, but the capital base is to be preserved in perpetuity.

It can be argued that mineral development can contribute to sustainable development in this case even if mining ends long before it is currently expected to do so, both because the agreement's cultural heritage and environmental management provisions will minimise any costs borne by future generations, and because they will enjoy a substantial and ongoing revenue flow, and the economic and social opportunities associated with it, that would not be available in the absence of mining. This final example highlights again the critical impact of public policies. Indeed it could be argued that the sustainability of mining in this case increased dramatically over a short period of time because of the High Court's recognition of indigenous rights in land, the federal government's action in giving legislative expression to this 
recognition, and the Queensland government government's decision to divert a share of its own royalty income into the WCCCA.

\section{Policy processes, policy outcomes and sustainability}

Public policies play a central role in determining whether or not mining will be sustainable. The content and outcomes of public policies are, in turn, intimately linked to the nature of public policy processes, a link that is well documented across a wide variety of political systems and policy contexts. For example Alston and his colleagues found that the 'driving force' behind policies in contemporary Brazil is the specific nature of interactions between key political actors in different policy arenas, and that 'the dynamics of the policymaking game' in these arenas yield predictable outcomes in terms, for example, of the stability and adaptability of policy. The specific features of policy making processes are in their view 'key determinants of the characteristics of public policies', characteristic they label as 'the dependent variable' (2006 Alston et al 2006, 6-11). Howlett found that the nature of policy-making subsystems in Canada influenced both the pace and nature of policy change, and that changes in policy making processes were linked in a predictable manner to changes in the nature and rate of policy change (for other examples see Aininat et al 2006; Connick and Innes 2001; Gains 2003; Stein et al 2008). At a more specific level, Howard (2007) shows how one aspect of the policy process, the availability to participants of information on the probable impact of policy alternatives being considered, influenced the likelihood of departures from the status quo in relation to water management policy in Australia. Stratford and Jaskolski (2004, 321-32) argue that another specific aspect of the policy process, absence of appropriate leadership, acted as a barrier to the development of policies conducive to sustainability in local government in Tasmania.

As noted earlier, in the context of sustainability in mineral industries considerable attention has focused on the link between public participation in policy making processes and the nature of policy outcomes, generally based on an assumption that greater public participation increases the likelihood that public policies will promote sustainability and, according to some analysts, that it is indispensable to the pursuit of sustainability (Clark and Clark 1999, 189; MMSD 2002, 346). However the nature of any causal relationship between the extent of public participation and public policy outcomes requires investigation, and in addition the extent of public participation is only one of many variables that shape the nature of policy making processes. The following sections discuss nine such variables and the way, both individually and in combination, they relate to sustainability. The variables and some key questions in relation to each are presented in Table 1 . I have identified these variables based on a review of general literature on public policy making (for example Hogwood and Gunn 1989; Lindblom 1993; Pal 2006; Parsons 1995); and the literature on sustainability in mineral industries (for instance Environmental Law Institute 2004; Labonne 1999; MacDonald and Gibson 2006; MMSD 2002; Warhurst and Mitchell 2000; Weitzner 2002). 
I do not claim that this analysis is comprehensive, and accept that other variables may be relevant in particular cases, that individual variables considered here require more extensive analysis, and that further research is also needed to explore the way in which they inter-relate and the manner in which they link to sustainability. The objective is to demonstrate the need for a systematic analysis of the variables involved in public policy making and of their role in relation to pursuit of sustainability in mineral industries, and to offer an initial contribution to such an analysis.

\subsection{Inclusion: who is involved in policy making?}

The first issue involves the identity and interests of those who participate in policy making. Sustainability will not be prioritised if those participating in decision making do not value it and if those who do value sustainability are excluded. The importance of this issue is highlighted by the examples discussed earlier. For instance over some 60 years almost no provision was made for investment of Nauru's phosphate revenues in economic, environmental or social sustainability, because policy making involved only the colonial powers and they were not concerned about Nauru's sustainability, but rather about securing cheap and reliable supplies of phosphate for farmers in their home countries (Weeramantry 1992).

Historically, policy making in Australia and other free market economies has been dominated by individual mining companies, mining industry associations and government agencies (in particular treasuries and mines and energy departments). Companies play a critical role as mineral development is driven fundamentally by their investment decisions (where to explore, what to explore for, which projects to develop, which projects to close and when to close them), and because larger companies in particular have substantial capacity to lobby public policy makers. At a broader level industry associations also have a significant capacity to influence 
Table 1: Nine Variables that shape the character of Public Policy Processes

\begin{tabular}{|l|l|}
\hline Variable & Some key questions \\
\hline 1. Participation in decision making & $\begin{array}{l}\text { Who participates and who is excluded? What } \\
\text { mechanisms foster, or militate against, } \\
\text { inclusion? How much priority do those } \\
\text { included/excluded attach to sustainability? }\end{array}$ \\
\hline 2. Authority over outcomes & $\begin{array}{l}\text { What sources of power are available to } \\
\text { participants? Who has the capacity to determine } \\
\text { outcomes? How 'open' or 'closed' is decision } \\
\text { making in terms of participation and influence } \\
\text { over outcomes? }\end{array}$ \\
\hline 3. Decision alternatives & $\begin{array}{l}\text { What range of alternatives is considered? How } \\
\text { do these relate to the policy 'status quo'? How } \\
\text { is the range of alternative affected by the degree } \\
\text { of openness in decision-making? }\end{array}$ \\
\hline $\begin{array}{l}\text { 4. 'One off' or adaptive decision } \\
\text { making }\end{array}$ & $\begin{array}{l}\text { Do policy decisions tend to be 'one off', or can } \\
\text { they be revisited regularly? What are the } \\
\text { implications of this for sustainability? }\end{array}$ \\
\hline 5. Time allocated for decision making & $\begin{array}{l}\text { How much time is available for policy making? } \\
\text { How and by whom is this determined? Does } \\
\text { time for decision making accommodate cultural } \\
\text { differences? }\end{array}$ \\
\hline $\begin{array}{l}\text { 7. Time period over which effects of } \\
\text { policy decisions considered }\end{array}$ & $\begin{array}{l}\text { What resources are available to support } \\
\text { decision making, and to whom are they } \\
\text { available? Are there major disparities in the } \\
\text { resources available to different participants? }\end{array}$ \\
\hline policy making available to support & $\begin{array}{l}\text { What time frames are utilised? Who determines } \\
\text { these time frames? }\end{array}$ \\
\hline $\begin{array}{l}\text { What sorts of information are available to } \\
\text { inform policy making? Are specific types of } \\
\text { information privileged, or discounted? }\end{array}$ \\
\hline $\begin{array}{l}\text { What impacts and issues are considered in } \\
\text { policy making, and which excluded? What } \\
\text { weight is attached to various impacts? What } \\
\text { methodologies are used in assessing impacts, } \\
\text { and are some privileged over others? }\end{array}$ \\
\hline
\end{tabular}


government both directly by lobbying, and indirectly by helping to mobilise public opinion around specific issues such as land access and indigenous rights (Libby 1989; Lindblom 1993).

Mining companies may be very concerned about sustainability in corporate terms, in other words in ensuring that they achieve the levels of profitability and growth required to ensure their own survival in a competitive environment. However they do not necessarily attach priority to the economic, social or environmental sustainability of individual communities, regions or countries (Trebeck 2007). While in theory democratic governments should reflect the diversity of interests that comprise their electorates, in reality they have often been driven by the need to demonstrate their ability to foster economic growth, particularly by supporting large projects that offer highly visible additions to employment and exports. As a result they have in the past prioritised rapid development of mineral resources (Harman and Head 1981, Howlett 2007).

More recently the introduction of environmental impact assessment legislation has provided an opportunity for other interests to participate in public policy processes, for instance through public submission and objection processes that allow interested groups to argue that projects should not proceed, should be modified substantially before proceeding, or should be subject to environmental and other conditions (Cheney et al 2002, 2). Legal recognition of indigenous rights has provided an avenue for indigenous participation in decision making. Under Australia's NTA registered native title claimants have a 'Right to Negotiate' with applicants for mining leases and with relevant state authorities regarding the terms on which development can occur. The opportunity to negotiate with developers and governments allows native title groups to articulate their views on mineral development, and some have concluded legally-binding agreements that impose conditions on mining projects related to economic, social and environmental sustainability (O'Faircheallaigh and Corbett 2005), a point illustrated by the earlier discussion of the WCCCA.

Finally, the adoption of corporate social responsibility policies by many of the world's leading mining companies (MMSD 2002, ICCM 2008) creates another opportunity to expand the range of interests involved in policy making. Many major companies have established policies that require systematic identification of and engagement with their stakeholders, including community, environmental and indigenous groups. BHPBilliton, for instance, requires all of its sites 'to identify their key stakeholders and consider their expectations and concerns for all operational activities, across the life cycle of operations. Sites are also required to specifically consider any minority groups (such as Indigenous groups) and any social and cultural factors that may be critical to stakeholder engagement’ (BHPBilliton 2008).

\subsection{Authority: who determines policy outcomes?}

Participation in decision policy making is one matter, but the capacity to determine outcomes is another (Howard 2007). Companies and governments have sources of power and influence that are unequivocal and substantive, and particularly in relation to individual projects each enjoys a 'yes/no' power of decision over whether or not development will proceed. Companies have an investment veto, as in a market economy government cannot force companies to invest. Governments have a 
regulatory veto, as projects cannot be developed without government approvals. The power to decide whether or not a project will proceed provides both parties, in turn, with substantial influence over a range of other decisions, as companies and governments can insist that they will only invest in a project, or approve a project, under the 'right' conditions. For companies, these conditions may relate to royalty rates, public funding of mine infrastructure, project scale, or environmental conditions. For governments, they may relate to company funding of infrastructure that will have multiple users, domestic processing of minerals, or allocation of a proportion of energy output to domestic markets.

The capacity of environmental, community, or other civil society groups to shape policy outcomes is less clear cut. It can be substantial in some cases. For example environmental groups successfully mobilised public opinion and lobbied Australia's federal government to maintain a ban on development of new uranium projects for more than a decade after 1983. Environmental groups prevented development of the proposed Windy Craggy copper mine in British Columbia in 1993. However in relation to mining projects that do not attract widespread public attention because of the mineral being mined or of their location in environmentally or culturally sensitive areas, in reality the vast majority, the power of environmental or community groups in public policy making is still limited. For example over the last 30 years their political actions have resulted in only a handful of mining projects in Australia and Canada being refused development approval or being substantially modified.

In some cases indigenous people have a legal right to determine whether or not development can proceed. For instance in Australia's Northern Territory Aboriginal people granted freehold title under the Aboriginal Land Rights (Northern Territory) Act 1976 must consent to the grant of exploration and mining leases, allowing them to exclude mining altogether from areas they regard as highly sensitive. Their veto also allows them to apply stringent environmental and cultural heritage protection to, and obtain substantial economic benefits from, projects they do allow to proceed. In combination such actions have the potential to greatly enhance the contribution of individual mining projects to economic, social and environmental sustainability, especially where revenues extracted through negotiated agreements are invested in social and economic development in areas where mining is prohibited

(O’Faircheallaigh 2002). Indigenous people may be able to use political pressure to win for themselves a de facto right of veto even where such a right does not exist in law. For example after Innu and Inuit traditional owners halted development of Inco's Voisey's Bay nickel project through direct action and litigation, the Government of Newfoundland and Labrador informed Inco that it would not allow the project to proceed without the consent of the Innu and Inuit (Newfoundland and the Innu Nation, 2002). Voisey's Bay provides a clear example of the way in which control over decision making affects the sustainability of mining. One of the conditions on which the Innu and Inuit eventually allowed the project to proceed was that annual nickel output would be less than half that originally planned. This reduced environmental impacts and provided local communities much more time to capitalise on opportunities created by Voisey's Bay (for instance skills and enterprise development), allowing them to build an economic base that could survive the end of mining. 
While the NTA does not confer a veto on Aboriginal landowners in Australia, it does give them some capacity to influence outcomes through their right to negotiate with governments and developers, a capacity bolstered by their ability to use their procedural rights to delay projects if agreement is not reached. The evidence suggests that Aboriginal groups that are cohesive, well organised and reasonably well resourced have been able to use the NTA to enhance environmental and cultural heritage protection and extract significant economic benefits. However to date there have been few if any cases where it has been used to prevent mining in specific areas or to change project configurations in the way achieved at Voisey's Bay (O’Faircheallaigh 2008; O’Faircheallaigh and Corbett 2005).

The extent to which policy processes incorporate, and confer power upon, a wide and diverse range of interests determines the degree of openness that characterises policy making. A process that incorporates or confers authority only on mining companies and government economic agencies, for example, could be characterised as highly closed. A process that also involved and conferred influence on a range of other actors including government agencies operating in environmental and social fields and environmental, indigenous and community groups could be described as highly open. It is useful to think of various configurations as aligned along a spectrum which includes many different approaches, including for instance ones where the canvassing of policy options is very open, but where the making of final decisions is closed. There can be tension between the degree of openness of a policy process and its capacity to generate binding and timely decisions, with the possibility that excessive openness can result in 'policy paralysis' arising from the fact that multiple contending interests exercise a capacity to veto decisions they do not approve of (Jones 2001). What is required to promote sustainability in mineral industries is a balance that confers a degree of power on groups that have most to gain from sustainable outcomes, but does not create a policy system so open and fluid that it destroys the certainty needed to facilitate large capital investments in resource projects. Achieving this balance in practice is a substantial challenge. Its pursuit must begin with recognition of the need to reform the traditionally closed policy systems that have operated around mineral industries.

\subsection{Policy alternatives}

Policy processes can vary according to the range of policy alternatives that are considered. In some cases an incremental approach is adopted, with only a narrow range of alternatives, representing minor adjustments to the status quo, being considered. At the other end of the spectrum, the full range of conceivable alternatives may be evaluated (Pal 2006, 271-93). In the context of mineral development and sustainability, an incremental approach might involve a continuation of traditional approaches based essentially on economic calculations, with gradual adjustments being made to project design and operations to enhance environmental and social sustainability. These might involve, for instance, reduction of water and energy consumption (which may of course improve project economics in any case), or establishment of corporate foundations to channel additional social benefits to affected communities. Alternatively a much wider and more radical range of alternatives might be considered. These could include fundamental changes to project scale and design to enhance sustainability, and a 'no project' alternative where prospects for sustainability appear poor. The latter alternative is sometimes 
considered in conventional EIA, but usually immediately dismissed on the basis of the economic benefits that would be foregone (see for instance Chevron Australia Pty Ltd $2005,14)$. It can be argued that given the magnitude of environmental and social problems associated with recent patterns of industrial development, an incremental approach is no longer adequate, because at least in the short to medium term it replicates approaches that have caused the problems in the first place.

The range of decision alternative considered is linked to the openness of decision processes. A closed process dominated by interests that have benefited from the status quo is likely to be associated with an incremental approach to policy making, and unlikely to facilitate a consideration of radical alternatives, whereas 'opening up' the decision process is likely to have the opposite outcome. This is illustrated by the example of Voisey's Bay. It is very unusual for a mining project to proceed at half the scale identified as optimum by the project proponent, and this outcome followed on from the success of the Innu and Inuit in 'opening up' the decision process and establishing themselves as powerful actors within it.

\section{4 'One off' versus adaptive policy making}

Another dimension of policy making involves the issue of whether a process focuses on single, 'once and for all' decisions in relation to mining projects, or creates systems that allow for ongoing, adaptive changes to project design and operation. Historically, the emphasis has been on the former, with a single critical set of decisions determining whether a project can proceed and, assuming it can, the conditions under which it will operate for the remainder of project life or at least over long periods of time. Governments tend to impose or to negotiate provisions on key issues such as royalties, mineral processing, and infrastructure provision with potential investors in a new mine, and to leave these in place for the whole of project life. In Australia, the agreed conditions are often enshrined in legislation, creating additional barriers to their amendment (Fitzgerald 2002). Such an approach has been deemed essential in order to provide the certainty demanded by potential investors (MacDonald and Gibson 2006, 14). Similarly, EIA processes generally produce one decision, or one advice to government, as to whether a project should proceed, and establish a single set of environmental or other conditions that will be in place indefinitely (Howitt 2001, 337-38; Joyce and MacFarlane 2001, 3, 12;

O’Faircheallaigh 2007, 322-33). These matters are rarely revisited. I am not aware of any legislation, for example, that requires a further EIA to be undertaken after, say, 10 years, to establish whether project impacts are as expected and whether the decision to allow the project to operate, or the conditions imposed on it, should be revisited.

It can be argued that such an approach is inadequate if sustainability is to be achieved. Given the rapid changes that can occur in understanding of environmental and social impacts and in mining, mineral processing and waste treatment technologies, it may be essential to develop 'adaptive' approaches that regularly revisit relevant issues and enhance responses to them. The requirements for adaptive management have started to attract substantial attention in the academic literature, and attempts are being made to apply them in environmental management of some projects (Morrison-Saunders and Arts 2005; O’Faircheallaigh 2006). However it can be argued that policy making systems are still very much dominated by a 'one off' approach, as indicated by the 
fact that even where adaptive approaches are required by legislation, they are rarely applied in practice (O’Faircheallaigh 2007).

\subsection{Time allocated for policy-making}

The time period allowed for policy making is an important variable because it influences the potential to involve a range of interests in decision making and the way in which they can be involved. It also shapes the type and range of information considered in making decisions (discussed below), for instance because considerable time may be required if policy makers are to gain access to information dealing with long-term natural cycles, or information from oral sources such as interviews with indigenous elders. Generally speaking, the shorter the time frame applied, the narrower the opportunities that exist in terms of involving diverse interests and a wide range and depth of information. Particular problems may arise where significant cross-cultural differences exist in policy making processes. For instance in some indigenous societies decision making is highly consensual and time consuming, and it may prove impossible to establish and articulate indigenous positions within the time frame allowed by mainstream policy processes.

Two influences tend to be paramount in setting time frames for policy making in mineral industries. The first are statutory requirements, with mining, environmental impact assessment and native title legislation usually establishing requirements on government to take decisions within specific time periods (see for instance Western Australia 2008). The second are the financial and market pressures facing mining and energy companies, which often mean that they are working to tight time frames, especially if they are competing with other potential suppliers to meet limited market opportunities.

Decision making time frames for major mining projects are not always unduly short. For example most legislation allows government ministers some discretion to extend statutory time frames. In some cases companies may be developing projects over extended periods of time as part of long-term development and production schedules, for example when they hold long-term contracts and/or are mining raw materials for use in vertically-integrated operations. However in general companies tend to press hard to minimise decision making time frames, to some extent because they want to build in some 'fat' in case of unforseen delays arising from other factors.

Governments tend to be responsive to what they see as commercial imperatives. The result can be that insufficient attention is paid to sustainability issues in policy making. This is not to argue for open ended time frames. Market and financial imperatives are real, and a project that ends up being uneconomic because it has missed a market opportunity is of course incapable of contributing to sustainable development. However sustainability in mineral industries cannot be achieved if time frames for decision making make it impossible to incorporate those with a strong interest in sustainability, or to gather and analyse information that is critical in establishing requirements for sustainability. Thus if mineral and energy industries are serious about pursuing sustainability, they cannot insist that time frames be driven solely by commercial factors. 


\subsection{Resources available to support policy making}

Another important variable involves the availability of resources to support participation in policy making. Corporations fund their participation in decision making on the assumption that they can recoup their costs from projects that proceed, and government agencies and actors have access to public budgets. For other potential participants, in particular indigenous and civil society groups, obtaining the resources required to participate in policy making is often difficult. In certain jurisdictions (for instance Canada) intervener funding is sometimes available to support participation in EIA processes. However the resources involved are often very limited, for example a total of C $\$ 1.5$ million for all non-government groups wishing to make submission to the EIA for the Mackenzie Valley Pipeline, one of Canada's largest proposed resource projects (Green 2008). In addition, EIA constitutes only one stage of a decisionmaking process that begins with an application for exploration licences and ends only with project decommissioning.

Indigenous groups face particular challenges because their members tend be economically disadvantaged and to live in remote regions. The latter means that the cost of bringing people together to discuss proposed projects is high, especially as consensual decision making approaches can require multiple meetings. The cost of making representations to governments in distant capital cities is similarly high. Acquiring access to the technical expertise required to participate effectively in decision processes is also costly. While resource constraints may not stop indigenous, environmental and community groups from participating effectively, they often do require them to focus their efforts on a small number of projects and to ignore others, an outcome which may have important implications for sustainability. For instance many of the Native Title Representative Bodies that represent Aboriginal landowners in Australia regularly ignore a large proportion of notifications in relation to exploration permits and decline to take advantage of relevant procedural rights because they lack the resources to do more than focus on a small number of mining lease applications whose potential impacts are immediate and substantial (Corbett and O'Faircheallaigh 2006, 174). One important consequence of this situation is that cumulative impacts of multiple developments, many of which escape any scrutiny, cannot be addressed.

The resources available to support policy making and the time available for making decisions are inter-related, but in ways that are variable and contextual. For example, provision of additional resources can allow specific activities required for policy making (for instance collection of information) to be undertaken more rapidly. On the other hand resources may be used wastefully if insufficient time is available to develop a coherent and logical plan to identify, collect and analyse relevant information.

\subsection{Time periods over which effects of policy alternatives are}

\section{considered}

Central to the concept of sustainability is a consideration of the effects of current actions and choices on future generations. Thus the time frame over which the policy process considers the impact of policy alternatives is critical. If future generations are 
to be considered, time frames must obviously be extended (for instance 60 -100 years if the impact on two generations is to be considered).

In reality the time frames over which the impacts of major mining and energy projects are analysed as part of public policy making are generally much shorter than this. Typically the time frame on which attention is focused is the life of project (see for instance Blacktip Joint Venture 2004; Moolarben Coal Mines Pty 2006a). This can be as short as 10 years. The assumption generally is that economic impacts, for instance, only need to be considered during project life, and that environmental impacts will be remediated before a project is abandoned. In reality while the direct economic impacts of a project may largely coincide with its productive life, its indirect effects may last longer (see Bowes-Lyon et al, this volume), and indeed must last longer if the project is to make a lasting contribution to economic sustainability. There are many cases of 'legacy' mines whose environmental impacts persist long after mining has stopped (MMSD 2002, 407-408), and as the earlier discussion of Nauru illustrates, social impacts can also be long lived. Thus a policy process that considered whether a project would generate net public benefits over an operational life of 20 years might yield a different outcome to one that assessed net benefits 40 years.

\subsection{Information for policy making}

If decision making is to attach value to and promote sustainability, then decision makers must have access to relevant information, and in particular to information regarding the likely impacts of proposed projects over extended periods of time, without which likely impacts on future generations cannot be assessed. Projects approved in the absence of such information will not necessarily be unsustainable, but in the absence of the requisite information policy makers cannot attach appropriate weight to the requirements for sustainability. Information must also be available to consider the various dimensions of sustainability (economic, environmental and social).

Given that the time frames over which project effects are considered are often short (see section 3.7), information regarding impacts on future generations is frequently unavailable. In relation to environmental impacts, an additional and particular problem arises from the fact that baseline data is often available only for the limited time period over which a project developer has been undertaking environmental studies in a particular area. Given uncertainty regarding the nature of the 'background' environment over longer periods of time, project proponents may argue that it is in fact impossible to accurately assess the implications of the impact represented by a mining project, and may use the absence of existing information as a rationale for not attempting to do so. Quite apart from the issue of whether projects should be approved if their long term impacts cannot be evaluated, application of traditional ecological knowledge (TEK) held by indigenous groups may assist in providing long term baseline information, given that the observations of living generations, combined with knowledge inherited from their forebears, can cover extensive periods of time. Given its overwhelmingly oral nature, access to that information requires the participation of the people who possess it. Some attempts have been made to incorporate TEK into decision making processes, for instance in relation to management of diamond mines in Canada's Northwest Territories, with limited success to date (O’Faircheallaigh 2006). As noted above issues relating to 
decision time frames, resources to support participation in decision making, and the legal rights of indigenous people must be addressed if indigenous people are to participate more activity and so make their TEK available to policy makers.

More generally, there has been a tendency to focus on assembling information relating to economic and environmental aspects of project impacts, and to pay considerably less attention to social impacts, with the MMSD noting, for instance, that social factors have only recently started to 'creep' into environmental impact assessment (MMSD 2002, xxi). In the absence of information on current social realities and the potential social impact of proposed mining projects, policy makers clearly cannot take into account the requirements for social sustainability. As noted earlier, failure to address these requirements can result in the abandonment of major ore bodies whose exploitation is viable in technical and economic terms.

\subsection{Criteria for policy making}

A final issue involves the decision criteria that are employed by policy makers. Which impacts are considered and which are excluded? What weight is attached to different impacts, for example as between economic, social and environmental effects? Are all potential impacts evaluated using similar methodologies? What weight is attached to short-term impacts as opposed to long-term impacts? To express this last point somewhat differently, what discount rate is applied by decision makers? Application of a high discount rate will mean that short term effects are weighted much more heavily than long term effects (MMSD 2002, 347), while use of a lower rate will moderate this effect. If appropriate decision criteria are not employed there is little prospect that policy processes will help ensure that mining promotes sustainable development, regardless for instance of what information resources or time frames are applied to policy making.

As indicated above, historically, assessment of mining projects has tended to focus almost entirely on economic criteria. This is evident, for instance, from the matters addressed in agreements under which Australia's state governments provided approval for major resource projects (Fitzgerald 2002, 139). Introduction of environmental impact assessment and environmental protection legislation in the 1970s required a focus on the physical environment, but a great deal of latitude remained and remains today in determining which environmental impacts or issues are taken into account. For instance in September 2007 Australia's Federal Court rejected an attempt by environmental groups to challenge the Federal Minister for the Environment's decision in relation to a proposed coal mine on the basis that the Minister had not properly assessed the adverse effects on greenhouse gas emissions that would be caused by burning coal produced by the mine.

There is also the issue of the relative weight attached by policy makers to economic and environmental impacts, however the latter are determined. As discussed above, a small number of projects in Australia have been substantially modified or halted because of their expected environmental impacts. But the vast majority are approved on the basis that their promised economic benefits exceed any potential environmental costs, and the significance of social and cultural impacts have continued to be downplayed, if not excluded, by policy makers. Where social or cultural effects are considered the analysis often lacks the rigorous, quantitative methodology analysis 
applied in assessing economic impacts (see for instance Dames and Moore 1994; Chevron Australia Pty Ltd 2005; Moolarben Coal Mines Pty Ltd 2006b). This is important, because it may be difficult for a policy maker to insist on project changes to address potential social and cultural impacts expressed in general, tentative or hypothetical terms, given anticipated economic benefits that are clearly quantified and substantial and so appear certain to eventuate.

Another key issue involves the discount rate applied to future expected costs and benefits. In calculating economic benefits of mining projects, the conventional approach for companies is to use a discount rate which is equivalent to their average cost of capital (van Rensburg and Bambrick 1978, 149, 153). Using a discount rate in the region of 10 per cent (van Rensburg and Bambrick 1978, 151-52), this would obviously render negligible the current value of any benefits or costs accruing to 'future generations', in comparison to short term benefits or costs. It should however be noted that companies undertake some exploration expenditures that are not expected to yield an income until a decade or more into the future, and in this case lower discount rates are presumably applied because such expenditure are indispensable to the long-term 'physical' and 'corporate' sustainability of mining. Public policy makers may use discount rates somewhat lower than companies, though treasury bond rates, which are sometimes used as a basis for discount rates, are often in the range of 5 - 10 per cent. If calculations are made over periods of 40 or 60 years, for instance, application of such discount rates would still have the effect of rendering negligible the current value of long-term benefits and costs. Other participants in policy making may prefer lower discount rates. For instance indigenous people who hope that their traditional territories will provide sustenance for future generations may not discount long-term environmental impacts at anything like as high a rate as would non-indigenous decision makers. At a more fundamental level, it can be argued that affording quantitative cost - benefit techniques such as discounting a central role in decision making immediately devalues the importance of factors that are not quantifiable or not easily quantifiable, such as indigenous attachment to ancestral land, unique cultural heritage values or ways of life, or biological diversity.

Application of alternative and non-conventional policy making criteria may not, it should be stressed, always result in potential mining projects appearing unsustainable, and so lead to a decline in the overall level of mineral development. For example potentially positive social and cultural impacts may be undiscovered where the focus of decision making is exclusively economic and/or environmental. If lower discount rates are applied, projects that would otherwise not be developed because they generate substantial long-term benefits but few short-term ones may appear sufficiently attractive to ensure their development.

\section{Case Studies}

The relevance and applicability of the nine policy process variables identified above can be illustrated through two short case studies related to contemporary energy development in Australia. 


\subsection{Liquefied Natural Gas in Western Australia}

During the last decade large reserves of natural gas, amounting by some estimates to a third of Australia's total reserves, have been located about 300 kilometres from the coast of the Kimberley region in northwest Western Australia, an area little affected to date by large-scale industrial development. Additional and highly prospective parts of the offshore will be made available for exploration in 2008. Natural gas will be piped ashore to gas processing and liquefaction plants, and converted into Liquefied Natural Gas (LNG), mainly for export, and Liquefied Petroleum Gas (LPG) and condensates for sale in domestic markets. A number of major oil and gas companies are now involved in development activity, usually as part of joint ventures, including Shell, Woodside, Total, and Inpex, a Japanese company whose largest shareholder is the Japanese government. Inpex's project is most advanced, with a site identified on the Maret Islands, some 70 kilometres from the Kimberley Coast, preliminary environmental and engineering studies completed, and a decision to proceed to FEED (Front End Engineering and Design) anticipated in the near future. Woodside is also actively engaged in site selection, with other companies expected to follow.

Given the very large gas reserves discovered to date and the prospect of additional discoveries, the physical sustainability of gas production seems assured for decades into the future. Gas development raises major issues in relation to the environmental, economic and social sustainability of coastal regions and the Aboriginal peoples whose ancestors have occupied the area for thousands of years. Construction of pipelines, the building and operation of LNG processing plants, and shipping of LNG raises issues regarding the integrity of coastal environments. These support the wildlife and fish populations on which many Aboriginal people depend for their subsistence, some of which (for example turtles) are also of great cultural significance. There are particular concerns regarding the possibility that the various companies that have discovered gas will each establish separate processing facilities, affecting in total large areas of coastline and generating cumulative impacts that might threaten the viability of coastal ecosystems (Rothwell 2008).

Environmental groups have tended to oppose gas development outright. For example the Wilderness Society argues that gas development in the Kimberley 'should be ruled out straight away as incompatible [with environmental values], destructive and inherently unsustainable' (Wilderness Society 2008). The position of Aboriginal groups including the regional land organization, the Kimberley Land Council (KLC) reflects the fact that Kimberley Aboriginal communities already face serious issues in terms of the social, cultural and economic sustainability of their communities. Less than 20 per cent of working-age Aboriginal people are in formal employment and there is a heavy reliance on welfare payments; life expectancy is some 20 years lower than for non-Aboriginal Australians; access to education and housing is poor; and serious social issues face communities, including substance abuse, family violence and child abuse. Aboriginal leaders and the KLC believe that against this background they cannot ignore the potential opportunities associated with gas development, for instance creation of educational and employment opportunities and provision of revenue streams that can create further economic opportunities and support health, housing and other services. Thus they favour what they call "responsible development", which involves the concept of one or two industrial hubs where all gas processing and related industrial facilities would be located, minimising potential 
environmental impacts and facilitating environmental monitoring. It also requires effective protection of the environment and of Aboriginal cultural heritage, and that Kimberley Aboriginal people share substantially in the benefits of resource development (KLC 2007a, 2008a).

Historically, policy making processes relating to mineral development in Western Australia have been dominated by mining companies and state government agencies whose central role is to facilitate and encourage resource exploitation. Policy has been driven by an 'ideology of development' which assumed that the interest of Western Australia were served by fostering development of the state's mineral resources as fully and as rapidly as possible. Policy making criteria reflected this assumption, and removal of any barriers to development has been a central policy objective. For example the State Government used police on a number of occasions to suppress attempts by environmental and Aboriginal groups to prevent exploration or mining in ecologically or culturally sensitive areas. Time frames for decision making reflected the needs of developers. The views of Aboriginal people or environmental or community groups were afforded scant regard, and no attempt was made to draw on TEK in policy making. Sustainability in any sense of the term was not a major focus of policy. One specific result of this policy approach has been the widespread loss of Aboriginal cultural heritage, including the complete destruction of a number of major Aboriginal sites by the Argyle diamond mine and extensive damage to some of the world's oldest rock art on the Burrup Peninsula (Dixon and Dillon 1990; Harman and Head 1981; Hawke and Gallagher 1989; Howlett 2007).

There are indications that public policy processes in relation to gas development will depart from the past in important ways. The recognition of native title has given Aboriginal a legal basis on which to be involved in policy making. This is reflected in the fact that Aboriginal traditional owners, supported by the KLC, have participated in negotiations with Inpex regarding its proposed Maret Islands processing plant, and with the Western Australian government regarding this project and gas development more generally. When traditional owners were concerned that negotiations with Inpex were not resulting in effective measures to protect cultural heritage and the environment, the KLC initiated legal proceedings to prevent the grant of licences that Inpex required for geophysical work on the Maret Islands (KLC 2007b). The company then quickly concluded protocols with traditional owners covering cultural heritage and its conduct of environmental studes.

As mentioned earlier the NTA does not give Aboriginal people a veto over decisions in relation to resource development. In 2006 and 2007 the Western Australian Prime Minister, Alan Carpenter, made a number of statements, including one before Parliament, stating that gas development in the Kimberley will not proceed unless is creates significant economic and social benefits for Aboriginal people and unless it has the support of Kimberley traditional owners (Carpenter 2006). The Deputy Premier and Minister for State Development, who has portfolio responsibility for gas development, reiterated this position in February 2008, stating that "LNG processing ... will only go ahead with the fully informed consent of the traditional owners and their substantial economic participation“ (Australian Broadcasting Commission 2008). Also in February 2008 the Western Australian and Federal governments released draft terms of reference for a strategeic assessment of a plan for a commonuser LNG precinct which state that the "informed consent" and "support" of 
traditional owners will be a condition of any site approval (Department of Industry and Resources 2008).

This approach represents a radical departure in the context of Western Australia and, if the State and Federal Governments adhere to their commitments, will afford Aboriginal people a central place in policy making. This in turn would mean that the criteria used in making decisions about resource projects will be considerably broader than in earlier decades. More generally, it would have major implications for the sustainability of gas development, because in other contexts Kimberley traditional owners have been willing to support resource development only where proposed environmental and cultural heritage protection measures have been enhanced, and when long-term investment funds and other initiatives to enhance economic and social sustainability have been established (Bergmann 2006; KLC 2008b).

Major issues continue to arise in relation to other policy process variables identified in the earlier discussion. Time frames for policy making continue to be influenced by developer schedules, and at times they are entirely inadequate to allow appropriate consutlation and decision making processes within Aboriginal communties. For example the Northern Development Taskforce established by the Western Australia Government to identify potential sites for a common-user LNG precinct informed the KLC in early December 2007 that it would determine a short list of approved sites by March 2008. Especially since large areas of the Kimberley are inaccessible for much of the intervening period because of the wet season, this time frame would make it impossible to effectively engage Aboriginal traditional owners in the process of identifying acceptable sites. This in turn could result in decisions that are not based on community consensus and so creating social discord and contribute to a loss of social capital over the long term.

In relation to resources to support Aboriginal participation in policy making, both Inpex and the Western Australian government have signed multi-million dollar agreements to help meet the cost of community consultations and to provide Aboriginal groups with access to technical expertise. On the other hand no effective use is being made of Aboriginal TEK in policy making, with Inpex's environmental studies, for instance, being undertaken with virtually no active Aboriginal input, despite repeated attempts by the KLC to secure the involvmenet of traditional owners. This failure has potentially serious consequences for the environment, especially given that Inpex's studies have only been under way for a few years and that its base line data is consequently very limited, severely curtailing the time frames over which potential environmental impacts of various decision alternatives can be reliably assessed. Traditional owners have already challenged the company's studies on turtle ecology on the basis that company counts of turtles yield numbers that bear little relationship to traditional owner observations over decades of turtle harvesting (KLC 2007c). In addition, the fact that governments and developers are ignoring and so devaluing TEK can create social disquiet and undermine the authory of Aboriginal elders, so disrupting the social sustainability of Aboriginal communities (Nadasdy 2003).

While gas development off the Kimberley coast is in its early stages, this case study highlights the interrelationship between various dimensions of sustainability, and also the possibility that mineral development may in some circumstances enhance the 
economic and social sustainability of affected communties. This is certainly what Aboriginal leaders believe will occur if gas resources are developed "responsibly". It illustrates again the significance of public policy processes, with recent changes in policy making in Western Australia likely to signficantly enhance the prospects of achieving development that is ecologically, economically, socially and culturally sustainable. The case study also reveals the variable and dynamic nature of policy processes, with some aspects of policy making (for instance the failure to utilise TEK) remaining unchanged at the same time as others (for example Aboriginal participation and the provision of resources to support it) are changing substantially.

\subsection{Uranium policy in Australia}

Australia accounts for some 38 per cent of the world's uranium reserves, but over the last 30 years its share of world output has always been well below this level, and currently stands at about 20 per cent (Commonwealth of Australia 2006a, 1). This situation reflects policy decisions by successive Australian federal and state governments to limit development of the uranium industry, primarily because of concerns regarding the potential impact of uranium mining on the environment and on Aboriginal people, and regarding the link between uranium production and nuclear proliferation (O'Faircheallaigh et al 1989). In 1977 the then Liberal/National Party federal government approved development of a number of major mines in the Northern Territory subject to their compliance with an extensive regulatory regime dealing with environmental management and rehabilitation, nuclear non-proliferation and monitoring of impacts on affected Aboriginal communities, and to the negotiation of agreements between project developers and affected Aboriginal communities (Commonwealth of Australia 1977). On coming to office in 1983 the Labor federal government imposed a prohibition on the development of any additional mines beyond the three mines then operating or under development (the 'Three Mines Policy'), a position it maintained until its removal from office in 1996. Prohibitions on uranium mining were also introduced by Labor governments at the state level, including in Queensland and Western Australia.

The Liberal/National party government led by John Howard, elected in 1996, was opposed to Labor's Three Mines Policy. Slow growth in the nuclear power industry and the associated low level of prices for uranium meant that little pressure existed to open new mines, while the earlier closure of the Nabarlek project meant that there was 'room' under the existing policy for the establishment of an additional mine, which occurred in 2001 with the opening of the Beverley project in South Australia. After the turn of the century this situation began to change as concerns regarding global warming led to renewed interest in nuclear power, and as uranium prices began to recover. In 2006 the Howard government decided to reassess Australia's policy on uranium mining and Australia's role in the nuclear fuel cycle, and the Federal Opposition Leader, Kim Beazley, indicated Labor's support for such a move.

In order to provide a basis for this assessment the Federal Government established, in June 2006, the Federal Government established the Uranium Mining, Processing and Nuclear Energy Review (UMPNER) ('the Review'). A Review Taskforce would undertake 'an objective, scientific and comprehensive review of uranium mining, value added processing and the contribution of nuclear energy in Australia in the longer term' (Commonwealth of Australia 2006b). The UMPNER also included an 
Expert Panel which would review scientific aspects of the Taskforce's findings. The Review's Terms of Reference required it to consider Australia's capacity to increase uranium mining and exports and the potential to establish other steps in the nuclear cycle in Australia; the extent to which nuclear energy could contribute to the reduction of greenhouse emissions; and health, safety and security implications of nuclear energy (Commonwealth of Australia 2006b, 137, 147).

The UMPNER released a Draft Report for public comment and for peer review by the Expert Panel on 21 November 2006 (Commonwealth of Australia 2006a), and submitted its Final Report to the Federal Government in December 2006 (Commonwealth of Australia 2006b). The Review supported expansion of uranium mining in Australia because of the additional economic opportunities this was expected to provide, and predicted that the development of a nuclear power industry in Australia could contribute significantly in achieving cuts in greenhouse gas emissions. It found that environmental and health and safety risks associated with uranium mining and disposal of nuclear waste are manageable, as are the risks of nuclear proliferation (Commonwealth of Australia 2006a, 1-10, 2006b, 2-9). The Review made no findings regarding the potential social impact of expanding the uranium industry, including its potential impact on Aboriginal people, and the issue is not even mentioned in the summary of either the Draft or Final Reports (Commonwealth of Australia 2006a, 1-10; 2006b, 2-9). The Review's Terms of Reference did not explicitly require the social sustainability of uranium mining to be addressed. The omission is nonetheless surprising given that, as mentioned above, opposition from Aboriginal people concerned at uranium mining's social impact had recently led Rio Tinto to abandon one of Australia's largest uranium deposits at Jabiluka, highlighting the link between social sustainability and 'the capacity to increase uranium production'.

Looking at the way in which decision making was configured in this case and beginning with the issue of participation in and influence over decision making, the first point to note is the composition of the Review Taskforce and Expert Panel. Of the six members of the Taskforce, 4 were nuclear physicists, one an energy economist, and the sixth the Chairman of a power generating company. Thus the Taskforce was heavily dominated by people associated with the nuclear and power industries, not in itself likely to encourage consideration of the full range of sustainability issues raised by uranium mining. The Expert Panel was somewhat more broadly based, but again consisted exclusively of people with a background in science and business and included no one whose professional expertise related to the social impacts of uranium mining (Commonwealth of Australia 2006b, 138-39; 147-150).

The Review received submissions from some 80 organizations and undertook 'consultations' with a similar number. The large majority of organizations making submissions were mining or energy companies, industry associations and environmental and anti-nuclear groups. None of the organizations that made submissions was Aboriginal, and none had a primary focus on social issues or delivery of social services (Commonwealth of Australia 2006a, Appendix C). The large majority of the 80 organizations consulted by the Taskforce was involved in the minerals and energy industries, whereas only three were environmental groups and one was Aboriginal (the Northern Land Council, which represents Aboriginal people in Australia's major uranium producing region in the Northern Territory). None of the 
Aboriginal organizations specifically affected by uranium mining (for instance the Gunjehmi Association, which represents the Mirrar owners of the Ranger and Jabiluka leases areas), were consulted.

The decision alternatives considered by the Review were limited, which is not surprising given that its Terms of Reference assumed a focus on expansion of the uranium industry and given the composition of the Review Panel and Expert Group. For instance there was no consideration of a 'no expansion' option for Australia's uranium industry based on pursuit of alternative energy policies as a means of reducing Australia's greenhouse emissions. Neither was there any consideration of an option for expansion of the uranium industry that would include a strong focus on social sustainability, based for instance on incorporating Aboriginal traditional owners into site selection and development planning in the way that is being attempted in relation to LNG development in Western Australia.

The time frame allocated for policy making could be regarded as very truncated. Only five months were available for the Taskforce to consider the wide and complex array of issues involved in expanding uranium mining and Australia's role in the nuclear fuel cycle, and only 3 weeks were available for preparation of submissions on the Taskforce's Draft Report. This would certainly be entirely inadequate, for instance, for any Aboriginal groups that wished to discuss the Draft with their constituents and prepare a response. Given that submissions on the Draft Report were due on 12 December 2006 and the Final Report was completed by the end of 2006, the Taskforce would only have had a matter of days to consider submissions. The Final Report does not indicate how many submissions were made or how they were addressed. The fact that the summary of the Draft and Final Reports are almost identical indicates that little opportunity existed for the Taskforce to pay any regard to the submissions.

As indicated earlier, a substantial number of the organizations that participated in the Review were individual companies or industry or professional associations, which would have access to substantial resources to support their participation, as would a number of major environmental organizations. However smaller environmental groups, NGOs involved in delivery of social services and Aboriginal groups have access to very limited resources. Indeed given that most Aboriginal organizations struggle to fund their 'core' organizational activities, some of which involve statutory obligations, their participation would have required provision of funding by the Taskforce or the Federal Government. In fact, no funding was provided by the Government to facilitate public participation in the UMPNER (Commonwealth of Australia 2006a). The fact that no public hearings were conducted as part of the Review also militated against more broadly-based public participation.

Given the time available to conduct its inquiry, the information base available to the Taskforce largely consists of existing research regarding economic, technical and environmental aspects of the uranium and nuclear industries. The Taskforce did commission three studies, dealing with greenhouse gas emission of nuclear energy; electricity generation and global developments in uranium markets. Given the time frames available, these studies also relied largely on collation of existing research (Commonwealth of Australia 2006b, 151, 155). There is no indication from its Draft or Final reports that the Taskforce sought, or had access to, information on the social 
sustainability of uranium; or regarding the environments that would be affected by an expansion of uranium mining, including Aboriginal knowledge of those environments; or regarding Aboriginal understandings of the environmental impact of existing uranium mines in Australia.

The criteria used in policy making related essentially to the achievement of economic growth (relevant in particular to an expansion of uranium mining) and to the need to reduce Australia's green gas emissions (relevant to the establishment of nuclear power generation). Other criteria related to the avoidance of any health and safety problems potentially associated with the uranium and nuclear industry (Commonwealth of Australia 2006, 7, 15). The implications of uranium mining for social sustainability was not utilised as a decision criteria.

In important respects the processes utilised in undertaking the UMPNER stand in marked contrast to those being employed in relation to LNG Development in Western Australia. This highlights the dynamic and variable nature of decision making processes even within a single jurisdiction, and the quite different implications for sustainability of different approaches to decision making.

\section{Conclusion}

Public policies are central to prospects for achieving environmental, economic and social sustainability in mineral industries. A failure to achieve these dimensions of sustainability can, in turn, destroy the viability of otherwise valuable ore bodies, as occurred with Panguna and Jabiluka, or mean that mining is ultimately unsustainable, as on Nauru and at Ok Tedi. On the other hand adoption of appropriate public policies can result in mineral development enhancing social, economic, cultural and environmental sustainability, as is occurring with bauxite mining in Western Cape York and as Aboriginal leaders hope will occur with gas development in the Kimberley.

The content and impact of public policies are shaped, in turn, by the nature of public policy processes. This fact is rarely recognised in the literature on sustainability in mineral industries, and there have been few if any atttempts to analyse the variables that determine the nature of policy processes, or their implications for sustainability. This chapter identifies nine key variables that characterise public policy processes in relation to mineral development, and offers an initial analysis of how they relate to different dimensions of sustainability and to each other. More research is needed in this area, but it is already clear that the way in which each variable is dealt with in specific policy processes has important implications for the prospects of achieving sustainabilty.

This point is well illustrated by approaches to public policy making in relation to gas development in Western Australia and to Australia's policy on uranium mining and nuclear energy. In the former case certain aspects of the policy process (for instance government recognition of the need for Aboriginal participation in and influence over policy making) are likely to enhance the prospects for sustainable development. The provision of government funding to Aboriginal groups to allow them to take advantage of opportunities for participation illustrates the way in which individual 
variables in the policy process are related. However the way in which other variables are being addressed (the short time frames applied to policy decisions, the failure to mobilise Aboriginal traditional knowledge for use by decision makers) is likely to militate against sustainability. The same applies more generally to policy making on uranium mining and nucelar energy. Here the failure to provide the funding or time required to allow participation by Aboriginal or environmental interests, to consider social sustainability as a decision criteria, or to consider more than a narrow range of decision alternatives will reinforce each other and undermine the prospects for sustainable development. In a wider context, to the extent that such approaches characterise public policy making in relation to the mineral and hydrocarbon industries, their sustainability will be under threat.

There is considerable scope for further research in relation to the nine "policy process variables" identified in this chapter. One issue is whether there are other important variables that should be considered. There is also a need for more detailed analysis of the way in which individual variables interact in actual policy making processes. Some insights into this area have been offered in the initial discussion of the nine variables and in the two case studies, but for instance more systematic attention could usefully be focused on the interaction between time, information and values (i.e. the time frames applied to the policy process, the information available to policy makers, the criteria applied in policy making, and the time periods over which the effects of policies are considered). Important insights could be gained by extending the focus to social and political contexts other than those involving indigenous peoples, which have been the major focus here. Finally, additional work is required to consider how analysis of the nine variables might be applied in policy making, for instance through use of a matrix that systematically relates the variables to different "dimensions" of sustainability (economic, social, environmental; or through development of a weighting system that affored greater importance to certain variables depending on the prevailing policy context and policy goals. 


\section{References}

Ali S, O’Faircheallaigh C (2007) Extractive Industries, Environmental Performance and Corporate

Social Responsibility. Greener Management International: The Journal of Corporate Environmental Strategy and Practice 52:5-16.

Alston LJ, Melo MA, Mueller B, Pereira, C (2006) Political Institutions, Policymaking Processes and Policy Outcomes in Brazil. Inter-American Development Bank, Washington DC.

Aninat C, Landregan J, Navia P, Vial J (2006) Political Institutions, Policymaking Processes and Policy Outcomes in Chile. Inter-American Development Bank, Washington DC.

Australian Broadcasting Commission (2005) Country Profile - Nauru

http://www.radioaustralia.net.au/news/countries/NAURU.htm, accessed 11 January 2008.

Australian Broadcasting Commission (2008) Minister accuses Opposition of ignoring Kimberley concerns. ABC News Online 28 February.

Banks G, Ballard, C (1997a). Introduction: Settling Ok Tedi. In Banks G, Ballard C (eds) The Ok Tedi Settlement: issues, outcomes and implications. Australian National University, Canberra, pp. 1-11.

Banks G, Ballard, C (eds) (1997b). The Ok Tedi Settlement: issues, outcomes and implications. Australian National University, Canberra.

Bergmann W (2006) Negotiating Prosperity: Maximising Resource Benefits to Our People. Keynote Address, Conference on Achieving Objectives: A New Approach to Land Claim Agreements in Canada. Ottawa, June.

BHPBilliton 2008. Our Stakeholders.

http://www.bhpbilliton.com/bb/sustainableDevelopment/ourStakeholders.jsp Accessed 12 March 2008

Blacktip Joint Venture (2004) Social Impact Assessment Blacktip Project Wadeye, Northern Territory. Impaxisa Consulting, Brisbane.

Bruntland G (ed) (1987) Our common future: The World Commission on Environment and Development. Oxford University Press, Oxford.

Cape York Land Council/Comalco, 2001. 'A Way Forward Together.' Press Release 11 March, Cairns. 
Carpenter A (2006) West Kimberley Onshore Liquefied Natural Gas Processing Facilities: Statement by Premier. Legislative Assembly, Western Australia, 21 November.

Cheney H, Lovel, R, Solomon, F (2002) People, Power and Participation: A Study of MiningCommunity Relationships. MMSD Australia, Melbourne.

Chevron Australia Pty Ltd (2005) Draft Environmental Impact Statement/Environmental Review and Management Programme Executive Summary. Chevron Australia Pty Ltd, Perth.

Clark AL, Clark JC (1999) The new reality of mineral development: social and cultural issues in Asia and Pacific nations. Resources Policy: 189-196.

COAG (Council of Australian Governments) (1992) Inter-governmental Agreement on the Environment. COAG, Canberra.

Commonwealth of Australia (1977) Uranium: Australia’s Decision. Australian Government Publishing Service, Canberra.

Commonwealth of Australia (2006a) Uranium Mining, Processing and Nuclear Energy - Opportunities for Australia? Draft Report. Department of Prime Minister and Cabinet, Canberra.

Commonwealth of Australia (2006b) Uranium Mining, Processing and Nuclear Energy - Opportunities for Australia? Department of Prime Minister and Cabinet, Canberra.

Connick S, Innes, J. (2001) Outcomes of Collaborative Water Policy Making: Applying Complexity Thinking to Evaluation. Institute of Urban and Regional Development, University of California, Berkeley.

Corbett T, O’Faircheallaigh C (2006) Unmasking Native Title: The National Native Title Tribunal's Application of the NTA's Arbitration Provisions. University of Western Australia Law Review 33(1): 153-177.

Dames and Moore (1994) The Century Project: Draft Impact Assessment Study Report, Volume 1, Volume 2, Volume 3. Dames and Moore, Brisbane.

Day JC, Affum, J (1995) Windy Craggy: Institutions and stakholders. Resources Policy 21: 21-26.

Department of Industry and Resources (Western Australia) (2008) Strategic Assessment Agreement, Terms of Reference, Draft Selection Criteria. www.doir.wa.gov.au accessed 17 March 2008 
Dixon R, Dillon M (eds) (1990) Aborigines and Diamond Mining: the politics of resource development in the East Kimberley. University of Western Australia Press, Nedlands.

Environmental Law Institute (2004) Prior Informed Consent and Mining: Promoting the Sustainable Development of Local Communities. Environmental Law Institute, Washington D.C.

Fitzgerald A (2002), Mining Agreements: negotiated frameworks in the Australian minerals sector. Prospect Media, Chatswood.

Gains F (2003) Executive Agencies in Government: the Impact of Bureaucratic Networks on Policy Outcomes. Journal of Public Policy 23(1): 55-79.

Gao Z, Akpan G, Vanjik J (2002) Public Participation in Mining and Petroleum in Asia and the Pacific: The Ok Tedi Case and its Implications. In Zillman DN, Lucas AR, Pring G (eds) Human Rights in Natural Resource Management. Oxford University Press, New York, pp. 679-693.

Green J (2008) Information Underload. Uphere Business (March): 23-27.

Harman EJ, Head B (1981) (eds) State Capital and Resources in the North and West of Australia. University of Western Australia Press, Nedlands.

Hawke S, Gallagher M (1989). Noonkanbah, Whose Land, Whose Law. Fremantle Arts Centre, Fremantle.

Hogwood BW, Gunn LA (1989) Policy Analysis for the Real World. Oxford University Press, Oxford.

Howard J (2007) Do stakeholder committees produce fair policy outcomes?. In Wilson AL et al (eds)

Proceedings of the 5th Australian Stream Management Conference. Charles Sturt University,

Thurgoona, 157-162.

Howard MC (1991) Mining, Politics and Development in the South Pacific. Westview Press, Boulder, Colorado.

Howitt R (2003) Rethinking Resource Management: Justice, Sustainability and Indigenous Peoples. Routledge, London and New York.

Howlett C (2007) The Role of the State in Mining Negotiations: A Case Study of the Century Mine, North Queensland. Doctoral dissertation, Griffith University, Brisbane. 
Howlett M (2002) Do Networks Matter? Linking Policy Network Structure to Policy Outcomes.

Canadian Journal of Political Science 35(2): 235-267.

ICCM (International Council on Mining \& Metals) (2008) Annual Review 2007: Essential materials, produced responsibly. ICMM, London.

Jones (2001) Political Parties and Policy Gridlock in American Government. Edwin Mellen Press, New York.

Joyce SA, MacFarlane M (2001) Social Impact Assessment in the Mining Industry. Mining Minerals and Sustainable Development, London.

Katona J (2002) Mining uranium and indigenous Australians: The fight for Jabiluka. In Evans G, Goodman J, Lansbury N (eds) Moving Mountains: Communities Conflict Mining \& Globalisation. Zed Books, London, pp. 195-206.

Kearney S (2008) Aussie police call on kids to help quell violence in Nauru. The Australian, 10 March.

Kirsch S (1997). Is Ok Tedi a precedent? Implications of the Law Suit. In Banks G, Ballard C (eds) The Ok Tedi Settlement: issues, outcomes and implications. Australian National University, Canberra, pp. 118-140.

Kirsch S (2004) Changing Views of Place and Time Along the Ok Tedi River. In Rumsey A, Weiner J (eds) Mining and Indigenous Lifeworlds in Australia and Papua New Guinea. Sean Kingston Publishing, Wantage (UK), pp.182-207.

KLC (Kimberley Land Council) (2007a) Sharing the Resource Boom Key to Aboriginal Employment. Media Release 30 November, Broome.

KLC (2007b) Kimberley Land Council moves to protect Maret Island from disturbance. Media Release 28 April, Broome.

KLC (2007c) Wayne Bergmann, Executive Officer, Kimberley Land Council, Pers. Comm., 17 May.

KLC (2008a) Informed Consent of Traditional Owners Key to Sustainable Gas Development in the Kimberely. Media Release 11 January, Broome.

KLC (2008b) Completed Agreements. http://www.klc.org.au/agrees_complete.htm accessed 18 March 2008 
Labonne B (1999) The mining industry and the community: joining forces for sustainable social development. Natural Resources Forum: 315-22.

Libby, R (1989), Hawke's Law: The Politics of Mining and Aboriginal Land Rights in Australia. University of Western Australia Press, Nedlands.

Lindblom, C E (1993) The Policy-Making Process. Prentice Hall, Englewood Cliffs, N.J.

Lyons M, Smuts C, Stephens A (2001) Participation, Empowerment and Sustainability: (How) Do the Links Work?. Urban Studies 38(8): 1233-1251.

MacDonald A, Gibson, G (2006) The Rise of Sustainability: Changing Public Concerns and Governance Approaches towards Exploration. Society of Economic Geologists Special Publication 12: $1-22$.

May R, Spriggs, M (eds) (1990) The Bougainville Crisis. Crawford House, Bathurst.

MMSD (Mining Minerals and Sustainable Development) (2002) Breaking New Ground: Mining Minerals and Sustainable Development. International Institute for Environment and Development, London.

Moolarben Coal Mines Pty Ltd 2006a. Moolarben Coal Project: Environmental Assessment Report Vol 1. Wells Environmental Services, East Maitland.

Moolarben Coal Mines Pty Ltd 2006b. Moolarben Coal Project: Socio-economic Impact Assessment. Hunter Valley Research Foundation, Hamilton.

Morrison-Saunders A, Arts J (2005) Assessing Impact: Handbook of EIA and SIA Follow-Up.

Earthscan, London.

Nadasdy P (2003) Hunters and Bureaucrats: Power, Knowledge and Aboriginal-State Relations in the Southwest Yukon. University of British Columbia Press, Vancouver.

Newfoundland, Innu Nation (2002). Memorandum of Agreement Concerning the Voisey’s Bay Project. St Johns.

O’Faircheallaigh C (2002) A New Model of Policy Evaluation: Mining and Indigenous People. Ashgate Press, Aldershot. 
O’Faircheallaigh C (2005) Creating Opportunities for Positive Engagement: Aboriginal People, Government and Resource Development in Australia. Paper presented to the International Conference on Engaging Communities, Brisbane, 12-17 August.

O’Faircheallaigh C (2006) Environmental Agreements in Canada: Aboriginal Participation, EIA Follow-Up and Environmental Management of Major Projects. Canadian Institute of Resources Law, University of Calgary, Calgary.

O’Faircheallaigh C (2007) Environmental Agreements, EIA follow-up and aboriginal participation in environmental management: The Canadian Experience. Environmental Impact Assessment Review 27(4): 319-342.

O’Faircheallaigh C (2008) Negotiating Protection of the Sacred? Aboriginal-Mining Company Agreements in Australia. Development and Change 39(1): 25-51.

O’Faircheallaigh C, Corbett T (2005) Indigenous Participation in Environmental Management of Mining Projects: The Role of Negotiated Agreements. Environmental Politics 14(5): 629-47.

O’Faircheallaigh C, Wade-Marshall D, Webb A (1989) Uranium in Australia: An Annotated Bibliography. Australian National University, Darwin.

Pal LA (2006) Beyond Policy Analysis. Thomson Nelson, Toronto.

Parsons, W (1995) Public Policy: An Introduction to the Theory and Practice of Policy Analysis. Edward Elgar, Cheltenham.

Richards JP, Dang T, Dudka SF, Wong ML (2004) The Nui Phao Tungsten-Fluorite-Copper-GoldBismuth Deposit, Northern Vietnam: An Opportunity for Sustainable Development. Explor. Mining Geol. 12:61-70.

Rothwell, N (2008) On the Brink. Weekend Australian Magazine 15-16 march 2008.

Stein E, Tommasi M, Scartascini C, Spiller P (2008) Policymaking in Latin America. Harvard University Press, Harvard.

Stratford E, Jaskolski M (2004) In pursuit of sustainability? Challenges for deliberative democracy in Tasmanian local government. Environment and Planning B 31: 311-324.

Van Rensburg WCJ, Bambrick S (1978) The Economics of the World’s Mineral Industries. McGrawHill Book Company, Johannesburg. 
Warhurst A, Mitchell, P (2000) Corporate social responsibility and the case of the Summerville mine. Resources Policy 26:91-102.

Weeramantry C (1992), Nauru: Environmental Damage under International Trusteeship, Oxford University Press Australia, Melbourne.

Weitzner V (2002) Through Indigenous Eyes: Towards Appropriate Decision-Making Processes Regarding Mining On or Near Ancestral Lands: Final Synthesis Report. The North-South Institute, Ottawa.

Western Australia (2008) Approval Flowchart - Environment Review and Management Program. www.doir.wa.gov.au/documents/investment/ERMP(i).pdf Accessed 12 March 2008

Wilderness Society (2008) A perfect storm is gathering in the Kimberley region of northern WA. http://www.wilderness.org.au/articles/kimberley-in-crisis accessed 2 July 2008. 